\title{
Lichens facilitate seedling recruitment in alpine heath
}

\section{Nystuen, Kristin O.}

2019-09

Nystuen , K O , Sundsdal , K , Opedal , $\varnothing \mathrm{H}$, Holien , H , Strimbeck , G R \& Graae , B J 2019 , ' Lichens facilitate seedling recruitment in alpine heath ' , Journal of Vegetation Science , vol. 30 , no. 5 , pp. $868-880$. https://doi.org/10.1111/jvs.12773

http://hdl.handle.net/10138/315292

https://doi.org/10.1111/jvs.12773

unspecified

acceptedVersion

Downloaded from Helda, University of Helsinki institutional repository.

This is an electronic reprint of the original article.

This reprint may differ from the original in pagination and typographic detail.

Please cite the original version. 
MS. KRISTIN ODDEN NYSTUEN (Orcid ID : 0000-0003-1027-469X)

Article type : Research article

Zaal Kikvidze

Title:

Lichens facilitate seedling recruitment in alpine heath

\section{Running title:}

Lichen-facilitated seedling recruitment

\section{Authors:}

Kristin O. Nystuen*, Kristine Sundsdal*, Øystein H. Opedal, Håkon Holien, G. Richard Strimbeck \& Bente J. Graae

*Shared first author

Nystuen, K. O. (Corresponding author, kristin.o.nystuen@ nord.no) ${ }^{1,2}$ http://orcid.org/00000003-1027-469X

Sundsdal, K. (kristine.sundsdal@gmail.com) ${ }^{1}$

Opedal, Ø. H. (oystein.opedal@helsinki.fi) ${ }^{3,4}$ https://orcid.org/0000-0002-7841-6933

Holien, H. (hakon.holien@ nord.no) ${ }^{2}$

Strimbeck, G. R. (richard.strimbeck@ ntnu.no) ${ }^{1}$

Graae, B. J. (bente.j.graae@ ntnu.no) ${ }^{1}$ https://orcid.org/0000-0002-5568-4759

This article has been accepted for publication and undergone full peer review but has not been through the copyediting, typesetting, pagination and proofreading process, which may lead to differences between this version and the Version of Record. Please cite this article as doi: $10.1111 /$ jvs. 12773

This article is protected by copyright. All rights reserved. 
${ }^{1}$ Department of Biology, NTNU, Norwegian University of Science and Technology, Høgskoleringen 5, P.O. Box 7491 Trondheim, Norway

${ }^{2}$ Faculty of Biosciences and Aquaculture, Nord University, P.O. Box 2501, 7729 Steinkjer, Norway

${ }^{3}$ Centre for Biodiversity Dynamics, Department of Biology, Norwegian University of Science and Technology, NTNU, 7491 Trondheim, Norway.

${ }^{4}$ Research Centre for Ecological Change, Faculty of Biological and Environmental Sciences, University of Helsinki, Helsinki, Finland.

\section{Author Contributions:}

KS, BJG, GRS, HH and KON designed the study; KS, KON and BJG did field work; KS performed the laboratory experiment; KON, ØHO and KS analyzed the data; KON and KS wrote the paper with inputs from all authors.

\section{Funding Information:}

This project had no external funding.

\section{Conflict of Interest Statement:}

The authors have no conflict of interest to report.

\section{Data Availability Statement:}

The two datasets analyzed in the current study are available in Supporting Information as Appendix S5 and S6.

This article is protected by copyright. All rights reserved. 


\begin{abstract}
Questions:

How do mat thickness, physical structure and allelopathic properties of terricolous matforming lichens affect recruitment of vascular plants in dwarf-shrub and lichen heath vegetation?
\end{abstract}

\title{
Location:
}

The mountains of Dovrefjell, central Norway.

\section{Methods:}

In autumn, seeds of ten vascular plant species were collected and sown in a common garden experiment with mats of six lichen species and bare-soil controls as experimental treatments. We recorded growing season soil temperature and moisture, and seedling recruitment and growth after one year. The effect of lichen secondary compounds on germination was tested in a growth chamber experiment and compared to the lichen-plant interactions detected under field conditions.

\section{Results:}

The lichen mats buffered extreme soil temperatures and soil drying in dry weather, with soils below the thickest mats (Cladonia stellaris and $C$. rangiferina) experiencing the lowest temperature fluctuations. Seedling recruitment and seedling growth in the field and seed germination in the lab were species-specific. Seedling recruitment rates were overall higher within lichen mats than on bare soil, but the $c .6 .5 \mathrm{~cm}$ thick mats of $C$. stellaris reduced recruitment of many species. The lab experiment suggested no overall strong effect of lichen allelopathy on seed germination, and effects on seed germination were only moderately correlated with the lichen-plant interactions observed for seedling recruitment in the field. 


\section{Conclusions:}

In harsh environments like alpine dwarf-shrub and lichen heaths, the presence of lichens and the resulting amelioration of the microclimate seems more important for vascular plant recruitment than are allelopathic effects often reported in lab experiments. We might therefore expect most terricolous lichens, depending on the plant species in focus, to facilitate rather than hamper the early stages of plant recruitment into lichen-dominated arctic-alpine heath vegetation.

\section{Keywords:}

Alectoria; Cetraria; Cladonia heath; Flavocetraria; Ground lichen; Lichen secondary metabolites; Lichen-plant interaction; Microclimate; Seedling emergence; Soil moisture; Stereocaulon; Tundra; Vascular plant colonization

\section{Introduction}

Terricolous lichens (i.e. lichens growing on soil) dominate the vegetation of roughly $8 \%$ of terrestrial ecosystems, among them arctic and alpine heaths (Ahti, 1977; Larson, 1987;

Crittenden, 2000; Nash, 2008). The species composition and abundance of terricolous lichens on arctic-alpine heaths vary with elevation, topography, and continentality (Haapasaari, 1988). Lichens are particularly dominant in convex parts of exposed and well-drained heaths (Crittenden, 2000; Vistnes \& Nellemann, 2008), where standing lichen biomass can reach $1200 \mathrm{~g} \mathrm{~m}^{-2}$ (Nellemann, Jordhøy, Støen, \& Strand, 2000). Terricolous lichens are ecologically important as the main food resource for reindeer and caribou in winter (Boertje, 1984; Danell, Utsi, Palo, \& Eriksson, 1994), and contribute substantially to the arctic-alpine carbon pool (Lange, Hahn, Meyer, \& Tenhunen, 1998). Species with $\mathrm{N}_{2}$-fixing cyanobacteria, such as

This article is protected by copyright. All rights reserved. 
Stereocaulon spp., further contribute to nitrogen enrichment of the often N-deficient heaths (Crittenden, 1989).

Recent studies report declines in lichen abundance in arctic-alpine areas (Fraser, Lantz, Olthof, Kokelj, \& Sims, 2014; Løkken, Hofgaard, Dalen, \& Hytteborn, 2019; Maliniemi, Kapfer, Saccone, Skog, \& Virtanen, 2018; Vanneste et al., 2017; Vuorinen et al., 2017), often driven by expansion of vascular plants, and in particular shrubs (Cornelissen et al., 2001; Fraser et al., 2014; Vanneste et al., 2017). Whether the negative effects of vascular plants on lichen communities are mediated by expansion of the already established plants within or close to lichen mats, or by colonizing plants from outside, is not known. Many lichens are indeed sensitive to shading from plants or their litter (Palmquist, 2008), whereas the low seedling densities often reported on arctic-alpine lichen heaths (Evju, Hagen, \& Hofgaard, 2012; Graae et al., 2011) suggest it is difficult for plants to recruit here. Plant recruitment in lichen heaths may be hampered by lichen secondary metabolites (i.e. allelopathy), by mechanisms related to the lichens' physical structure, or by harsh environmental conditions (Fig. 1).

In summer, lichen heaths often experience droughts, which Moles and Westoby (2004) identified as the second most important cause of seedling mortality. On the other hand, lichens modify microclimatic conditions in ways that may support seedling survival, as they maintain soil moisture (Broll, 2000; Kershaw \& Rouse, 1971; Molina-Montenegro et al., 2013) and prevent extreme temperatures due to high reflectivity and low thermal conductivity (Kershaw, 1977; Broll, 2000). Lichens furthermore reduce wind erosion and plant evapotranspiration through shelter effects (Molina-Montenegro et al., 2013).

This article is protected by copyright. All rights reserved. 
The physical structure of lichens may have contrasting effects on plant recruitment. Lichen mats act as efficient seed traps (Sedia \& Ehrenfeld, 2003), but can also prevent seeds or seedlings from reaching the ground. A classic example is Allen's (1929) observation of seedlings pulled out of the soil by repeated lichen thalli expansion and contraction driven by fluctuations in moisture. Some species (e.g. Cladonia stellaris) have upright, branched, shrub-like thalli, and form very thick and dense mats with low light penetration and high insulation capacity. Others (e.g. Flavocetraria nivalis) form upright, but thinner and more open mats that provide less thermal insulation (Crittenden, 2000), but may be easier for seeds and seedlings to penetrate. However, most lichen-plant recruitment interaction studies under field conditions have focused on Cladonia spp. (e.g. Allen, 1929; Brown \& Mikola, 1974; Hawkes \& Menges, 2003; M. M. Kytöviita \& Stark, 2009; Sedia \& Ehrenfeld, 2003) in various vegetation types, whereas less is known about the interactions between other ecologically successful genera of terricolous lichens (e.g. Cetraria, Stereocaulon and Alectoria; Crittenden, 2000) and plant species that co-occur in arctic-alpine vegetation.

Lichen secondary metabolites may also inhibit establishment and growth of vascular plants. Direct lichen allelopathic effects may inhibit germination, radicle and hypocotyl growth (Hobbs, 1985; Latkowska, Bialczyk, Lechowski, \& Czaja-Prokop, 2008; Nishitoba, Nishimura, Nishiyama, \& Mizutani, 1987; Peres, Mapeli, Faccenda, Gomes, \& Honda, 2009; Pyatt, 1967; Sedia \& Ehrenfeld, 2003; Tigre et al., 2012). Importantly, most findings of allelopathy are results from in vitro experiments, often with pure lichen compounds at high concentrations, and clear evidence for lichen allelopathy under natural conditions is scarce (Favero-Longo \& Piervittori, 2010). Under field conditions, allelopathy has been suggested to indirectly affect seedling growth by inhibition of soil microorganisms and mycorrhizal fungi (Brown \& Mikola, 1974; Fisher, 1979; Sedia \& Ehrenfeld, 2003), although the generality of 
these findings have been challenged (Kytöviita \& Stark, 2009; Stark \& Hyvärinen, 2003; Stark, Kytöviita, \& Neumann, 2007). Furthermore, the allelopathic effects depend on the specific secondary compounds and plant species in focus (Brown \& Mikola, 1974; FaveroLongo \& Piervittori, 2010; Hobbs, 1985; Peres et al., 2009).

Whether the lichens' negative effects via allelopathy and physical structure or facilitation via amelioration of the microclimate is more important for plant recruitment is an open question. Therefore, we here combine field and laboratory experiments to investigate how terricolous lichens affect the early recruitment phase of plants in dwarf-shrub and lichendominated heath vegetation typical for arctic-alpine areas. We test the response of plant species with different growth forms, seed sizes and seedling morphologies, which we expect to interact uniquely with the lichen species. In a field experiment, we aimed to answer the following questions: (1) Is soil microclimate (i.e. temperature and moisture) affected by lichen species and lichen mat thickness? Is (2) seedling recruitment and (3) seedling growth affected by lichen species and lichen mat thickness? Because allelopathy is hard to distinguish from other factors under natural conditions, we conducted a complementary laboratory experiment where we asked: (4) Is seed germination affected by lichen allelopathy? To reveal the importance of lichen allelopathy under natural conditions we asked: (5) Are the same lichen-plant interactions detected for seed germination in the laboratory and seedling recruitment in the field?

This article is protected by copyright. All rights reserved. 


\section{Methods}

\section{Study site}

The field study was conducted at an exposed dwarf-shrub and lichen heath, surrounded by subalpine birch forest in the mountains of Dovrefjell, Central Norway, close to Kongsvoll Biological Station (c. $930 \mathrm{~m}$ a.s.1., 62¹8'5.75517"N, 9³6'24.00385"E). The bedrock at the site consists of lightly eroded actinolite-hornblende amphibolite (Geological Survey of Norway, https://www.ngu.no/en/, accessed 11.07.17). The vegetation is dominated by Empetrum nigrum ssp. hermaphroditum, Arctostaphylos uva-ursi, Vaccinium vitis-idaea, Betula nana and Salix glauca, and the lichens Alectoria ochroleuca and Flavocetraria nivalis. Such dwarf-shrub and lichen heaths predominantly occur above the forest line, but can also be found on locally exposed areas within subalpine forests like our study site (Fremstad, 1998) (see Appendix S1 for photo from the study site). The studied dwarf-shrub and lichen heath is thus representative for such vegetation in general, and the findings especially relevant for arctic-alpine areas where these heaths are widespread.

Dovrefjell has a slightly continental climate with short warm summers and long cold winters. At the weather station Fokstugu (930 m a.s.l.) c. $26 \mathrm{~km}$ south of the study site, the mean annual precipitation was $435 \mathrm{~mm}$ (Førland, 1993) and mean annual temperature $-0.1^{\circ} \mathrm{C}$ (Aune, 1993) for the period 1961-1990. For the same period, the warmest month was July with average monthly temperature $9.8^{\circ} \mathrm{C}$ and the coldest was January, with $-8.8^{\circ} \mathrm{C}$ (Aune, 1993).

This article is protected by copyright. All rights reserved. 


\section{Lichen and seed material}

In a parallel field and laboratory experiment, we studied the interactions between six locally abundant terricolous lichen species: Alectoria ochroleuca, Cetraria islandica, Cladonia arbuscula, Cladonia stellaris, Flavocetraria nivalis and Stereocaulon paschale and 11 vascular plant species: Anthoxanthum nipponicum, Avenella flexuosa, Betula nana, Bistorta vivipara, Dryas octopetala, Luzula spicata, Pinus sylvestris, Salix glauca, Silene acaulis, Solidago virgaurea and Vaccinium myrtillus common in subalpine and low-alpine vegetation. These 11 plant species were chosen because they represent a variety of growth forms (tree, shrub, dwarf shrub, graminoid and forb), have been observed as adult plants growing within terricolous lichens (negative effects of lichen secondary metabolites on plant recruitment are more likely to have developed in co-occuring lichen and plant species; Hobbs, 1985), have seeds (bulbils for B. vivipara, hereafter referred to as seeds) of different sizes which might affect their recruitment potential, and have seedlings easy to distinguish from each other. The lichen species were chosen because of their dominance in arctic-alpine vegetation, and because they produce different secondary metabolites, have different growth forms (fruticose vs. cetrarioid) and physical structure of their mats (e.g. height and density), resulting in a variety of microenvironments for the recruiting plant species (Table 1).

The lichens and seeds were collected close to the study site in September and October 2013. For one species, P. sylvestris, seeds were supplied by The Norwegian Forest Seed Center and originated from Oppdal at $c .600-650 \mathrm{~m}$ a.sl., $c .35 \mathrm{~km}$ north of the study site. We planned to use all plant and lichen species in both the laboratory and field experiment, but due to seed limitation D. octopetala was used only in the laboratory and B. vivipara only in the field experiment. See The Norwegian Biodiversity Information Centre (NBIC) (https://www.biodiversity.no/, accessed 23.10.18) for unified nomenclature of lichen and plant species.

This article is protected by copyright. All rights reserved. 


\section{Field experiment}

In the field, seventeen plastic trays $(56 \times 26 \times 8 \mathrm{~cm})$ were divided into four plots each, for a total of 68 plots. Each plot was filled with one liter of commercial garden soil. The trays had holes to drain water, and the vegetation underneath was removed so that the plots were at level with the surrounding vegetation. Each of the six lichen species had eight replicate plots randomly assigned to the trays. Two types of controls were used with ten replicates each: (a) bare soil where seeds were sown, and (b) bare soil without seeds to control for external seed influx (see Appendix S1 for field design figure). At least one plot per tray was assigned to a control treatment, and each lichen species had one replicate per tray only.

For C. stellaris and C. arbuscula, coherent mats were collected and transplanted into the plots. As A. ochroleuca, C. islandica, F. nivalis, and S. paschale form less coherent mats, the plots were filled with several smaller lichen samples representing how they naturally grow. A mixture of 30 seeds from each of the 10 plant species, except for P. sylvestris with only 10 seeds and $S$. glauca with only 15 seeds due to limited seed availability, was sown on top of each lichen species and bare soil sowing control plot (the "lichen treatments") in October 2013. This gives a total of 265 seeds per plot, and as each plot was approximately $365 \mathrm{~cm}^{2}$, the seed density was 0.73 seeds per $\mathrm{cm}^{2}$. This density is higher than the expected natural seed rain in such vegetation (Graae et al., 2011; Molau \& Larsson, 2000), and ensured that seed availability would not constrain seedling recruitment. String was tied in a grid over the trays to prevent the lichens from being blown out. From October to May the trays were placed in a sheltered scrub community dominated by Salix spp., graminoids and bryophytes at the study site to reduce wind exposure during winter, and were moved c. $35 \mathrm{~m}$ to a neighboring exposed dwarf-shrub and lichen heath in late May, which is the most representative environment for the lichen species used in this experiment. 
In late May 2014, temperature loggers (NexSens Micro-T DS1921G) were placed 0.5 $\mathrm{cm}$ below the soil surface in each plot to measure the soil temperature every second hour. Soil moisture (\% volumetric soil water content) was measured once in each plot during overcast conditions after rain (26.08.14) and again during dry conditions on a sunny day after one day without rain (28.08.14) with a hand-held $5 \mathrm{~cm}$ long soil moisture probe set to option “organic soil" (TRIME-PICO, IMKO GmbH, Ettlingen, Germany). In late August and early September 2014, the temperature loggers were collected and the seedlings harvested. Mean, maximum and minimum temperatures were calculated for the period 13.06.14-31.08.14. Seedlings were identified, counted, rinsed in water to remove soil fragments, and oven dried at $70^{\circ} \mathrm{C}$ for 72 hours. All seedlings of each species from each plot were weighed together to obtain a measure of average dry seedling biomass (mg). The thickness of the lichen mats (average of 3 measurements from soil surface to highest lichen thallus point at different fixed locations) was measured for each plot at the end of the experiment (Table 1).

\section{Laboratory experiment}

In the laboratory, samples of each of the six lichen species were cleaned of debris, dried, and crushed with a hand blender. Two grams of crushed lichen was added underneath filter paper in five Petri dishes for each of the ten species sown and a control. Thirty seeds, except for $P$. sylvestris with 10 and S. glauca with 15 seeds, were placed on the filter paper and $6 \mathrm{ml}$ of distilled water was added. The controls had only filter paper, water and seeds. The Petri dishes were sealed with parafilm and kept in darkness at $3^{\circ} \mathrm{C}$ for 12 weeks. After this cold stratification, the Petri dishes were transferred to growth chambers (Percival E-36L) for 6 weeks with 20 hours daylight (representative for mid-June growing season photoperiod in central Norway) with approx. $200 \mu \mathrm{m} \mathrm{m}^{-2} \mathrm{~s}^{-1}$ photosynthetically active radiation at $20^{\circ} \mathrm{C}$, and 4 hours darkness at $10^{\circ} \mathrm{C}$. Every week, $2 \mathrm{ml}$ of distilled water was added, and the Petri dishes 
were rotated within the chamber. More water (1-2 ml) was added if signs of desiccation on the filter paper occurred. Germinated seeds were counted and then removed from the Petri dishes weekly over six weeks.

\section{Statistical analyses}

To test whether the soil microclimate was affected by the lichen treatments (question 1), we fitted linear mixed-effects models with Gaussian errors and with each microclimate parameter (mean soil temperature, maximum soil temperature, minimum soil temperature, soil moisture wet day and soil moisture dry day) as response variable, lichen treatment, lichen mat thickness and their interaction as fixed effects, and tray as random factor.

To test if seedling recruitment in the field experiment was affected by the lichen treatments (question 2), we fitted a generalized linear mixed-effects model with binomial errors and logit link-function, with proportion seedling recruitment as response variable, lichen treatment, lichen mat thickness, plant species and their interaction as fixed factors, and tray and plot (nested within trays) as random factors. In this analysis, plot was also included in the random structure because of several observations (i.e. plant species) per plot. Numbers of seeds sown for each species were added as weights in the models. For $V$. myrtillus, the only species with external seed influx from the control plots without sowing, the mean influx (0.7 seedling) was subtracted from the data prior to the analyses. Estimates were backtransformed (from logit scale to probability scale) to obtain recruitment rates, and these rates are presented in figures and text as they account for the nested structure of our experimental design.

This article is protected by copyright. All rights reserved. 
Similarly, to test if seedling biomass was affected by the lichen treatments (question 3), we fitted linear mixed-effects models with average seedling weight as response variable, lichen treatment, lichen mat thickness, plant species and their interactions as fixed factors, and tray and plot (nested within trays) as random factors. Seedling numbers were added as weights in the model because the number of recruited seedlings (i.e. the sample size) varied among plant species and plots. Two species were excluded from the field recruitment and growth analyses: $B$. nana because of low emergence rates in all treatments, and $S$. glauca because most seedlings were dead when counted and harvested in autumn (see Appendix S2 for counts of live and dead seedlings).

To test if seed germination in the lab was affected by lichen treatments (question 4), we fitted a generalized linear model with binomial errors and logit link-function, with the proportion of germinated seeds as response variable, and lichen treatment, plant species and their interaction as fixed factors. Estimates were back-transformed to obtain germination rates.

Finally, we used a Spearman rank correlation test to test for correlation between the field recruitment and laboratory germination estimates (question 5). Control treatments were excluded and only the seven plant species shared in both experiments were included.

To visualize the lichen-plant interactions in the field recruitment and lab germination experiment, and explore possible clusters, we constructed heat maps with hierarchical clustering (two-dimensional representations where the recruitment and germination estimates of all combinations of plant species and lichen treatments are shown with colors and ordered by similarity) with the gplots R package (Warnes et al., 2019). Dendrograms were

This article is protected by copyright. All rights reserved. 
constructed with hierarchical agglomerate Ward clustering based on Jaccard dissimilarities calculated in the vegan R package (Oksanen et al., 2017). Number of clusters for the lichen treatment and plant species dendrograms were manually chosen based on their separation heights and by visual inspection of the clusters' ecological meaning.

For question 1-4, model selection was based on the Akaike information criterion (AIC, see model selection results in Appendix S3). Small-sample corrected AIC $\left(\mathrm{AIC}_{\mathrm{c}}\right)$ was used for model selection in question 1. Anova and summary tables of models presented in the manuscript are in Appendix S4. Differences in soil microclimate among lichen treatments were tested using multiple comparisons with the Tukey method in the multcomp R package (Hothorn, Bretz, \& Westfall, 2008). For the mixed models (seed germination and seedling recruitment and biomass) we used the emmeans $\mathrm{R}$ package for pairwise comparisons (Lenth, 2017). All statistical analyses were done in R 3.1.2 (R Core Team 2015). Mixed-effect models were fitted with the lme4 R package (Bates, Mächler, Bolker, \& Walker, 2015). Primary data is available in Appendix S5 (seedling recruitment and seedling biomass in field) and Appendix S6 (seed germination in lab).

\section{Results}

\section{Soil microclimate - field experiment}

Lichen treatment was a better predictor of all soil microclimate variables than was lichen mat thickness (Appendix S3). The presence of lichens reduced mean and maximum soil temperatures and increased minimum soil temperatures compared to the bare soil control (Fig. 2a). Temperature buffering was strongest beneath C. stellaris and C. arbuscula (Fig. 2a), which had the thickest mats (Table 1). This was especially evident for maximum

This article is protected by copyright. All rights reserved. 
temperature, which differed by more than $20^{\circ} \mathrm{C}$ between $C$. stellaris $\left(24.9^{\circ} \mathrm{C}, 95 \% \mathrm{CI}=21.6\right.$ $-28.3)$ and the bare soil control $\left(45.7^{\circ} \mathrm{C}, 95 \% \mathrm{CI}=42.6-48.8\right.$; Fig. $\left.2 \mathrm{a}\right)$.

Soil moisture differed between treatments under dry conditions, but not under wet conditions (Fig. 2b). On the dry and sunny day, the driest soils occurred in the bare soil control $(8.6 \%, 95 \% \mathrm{CI}=6.9-10.3)$ and beneath $C$. islandica $(8.6 \%, 95 \% \mathrm{CI}=6.6-10.7)$, whereas the soils beneath $A$. ochroleuca $(13.1 \%, 95 \% \mathrm{CI}=11.2-15.0)$ and $C$. stellaris $(12.6 \%, 95 \% \mathrm{CI}=10.7-14.5)$ were moister $($ Fig $2 \mathrm{c})$.

\section{Seedling recruitment - field experiment}

The effects of the lichen treatments on seedling recruitment were complex and plant speciesspecific (Fig. 3), as demonstrated by strongest statistical support for the model including the plant-lichen treatment interaction (Appendix S3). For some plant species (B. vivipara and $L$. spicata) the lichen species did not seem to affect the recruitment, whereas for the other six plant species recruitment rates were overall higher and differed between lichen species, or between some lichen species and the bare soil control (Fig. 3). Most species had recruitment rates below 40\%, except $P$. sylvestris with recruitment rates approaching $80 \%$ (Fig. 3).

Based on their effect on seedling recruitment, the lichen treatments cluster into three groups: one with bare soil control only, one with $C$. stellaris only, and a third with the remaining five lichen species (Fig. 3b, Appendix S7). The bare soil controls stand out with overall low recruitment, and not a single seedling of B. vivipara and L. spicata recruited here (Fig. 3a). Many germinating seeds were observed on the bare soil controls during early summer (Kristin O. Nystuen, pers. obs.), suggesting high post-germination mortality. Compared to other lichen species $C$. stellaris supported low recruitment of many plant 
species, whereas for A. flexuosa the recruitment in C. stellaris was comparatively high (Fig. 3). The remaining five lichens supported higher recruitment overall, but still depending on the plant species in focus. Some of the species had relatively high recruitment rates within $S$. paschale, especially S. virgaurea (Fig. 3).

\section{Seedling growth - field experiment}

The lichen treatments' effects on seedling growth were species-dependent, as indicated by strongest statistical support for the model with lichen treatment-plant species interaction in Appendix S3. Most plant species had small seedlings below $5 \mathrm{mg}$ in dry weight, whereas $P$. sylvestris and S. virgaurea had heavier seedlings (Fig. 4). Seedling weight of these two species was also detectably affected by the lichen treatments, whereas for the remaining six species, with fewer recruited seedlings (Fig. 3), there were no statistically detectable differences among treatments (Fig. 4). Cladonia stellaris clearly affected the growth of $P$. sylvestris negatively, and weight of the seedlings here were only half the weight of the heaviest seedlings found in S. paschale and A. ochroleuca (Fig. 4).

\section{Seed germination - laboratory experiment}

Seed germination in the Petri dishes differed among plant species, and the lichen species had species-specific effects on the plant species (strongest statistical support for the model with plant-lichen treatment interaction; Appendix S3). Six out of ten plant species were detectably affected by the lichen treatments (Fig. 5a). The lichen treatments' species-specific influence on seed germination is also demonstrated in the heat map in Fig. 5b, where the lichen dendrogram did not separate until height 0.38 (Appendix S7), indicating that the treatments have few common effects on seed germination.

This article is protected by copyright. All rights reserved. 
For two plant species (S. acaulis and V. myrtillus) we found interesting patterns concerning lichen secondary compounds. Germination of S. acaulis was clearly enhanced in C. islandica and S. paschale (Fig. 5a), the only two lichens without usnic acid (Table 1), whereas Vaccinium myrtillus germinated best in $F$. nivalis and $C$. islandica, which are the only lichens with protolichesterinic acid (Appendix S2).

\section{Comparison between field and laboratory results}

Estimated recruitment rates in the field and germination rates in the laboratory were moderately correlated (Spearman's rho $=0.45, \mathrm{p}=0.003$ ), indicating only partial correspondence between the field and laboratory results.

\section{Discussion}

This study suggests that terricolous lichens facilitate rather than prevent seedling recruitment under stressful, natural conditions, and that the effects of lichens on seedling recruitment are related more to their physical structure and resulting microclimate modifications than to allelopathy. The lichen mats prevent large temperature fluctuations and conserve soil moisture, and this may have caused the increased recruitment we observed within lichen mats compared to on bare soil. Importantly, the effects of lichen mats on seedling recruitment and growth were species-specific, and for $C$. stellaris, a lichen with thick and dense mats, the overall facilitative effect was replaced by restrained recruitment and growth conditions for many plant species.

This article is protected by copyright. All rights reserved. 


\section{Damped microclimatic variation under lichens}

Microclimatic conditions strongly affect plant species distributions in alpine habitats and are known to vary across small distances (Graae et al., 2012; Opedal, Armbruster, \& Graae, 2015; Scherrer \& Körner, 2011). Our results suggest that some of this small-scale variation may be related to variation in lichen cover and assemblages, because the lichen species differ in their effect on microclimate. In general, temperatures beneath lichens were less extreme than on the bare soil controls. Large temperature fluctuations are favorable for germination of many species, especially those with small seeds and low competitive ability (Fenner \& Thompson, 2005). However, despite having the largest temperature fluctuations, the bare soil controls did not have higher recruitment rates of small-seeded species (such as L. spicata, S. acaulis and $V$. myrtillus). Furthermore, large temperature fluctuations can also be detrimental for seedlings (e.g. Cavieres, Badano, Sierra-Almeida, \& Molina-Montenegro, 2007), and the low recruitment we observed on bare soil may partly represent seedling mortality during summer. On bare soil, maximum temperatures reached $45^{\circ} \mathrm{C}, 10-20$ degrees higher than within the lichen mats, and soil drying was pronounced.

Under dry conditions, $C$. islandica was the only lichen below which the soil was as dry as in the bare soil controls. Lichen water absorption and retaining abilities may vary among species (Larson, 1979), and depend on morphology (Larson, 1981) and thallus size (Gauslaa \& Solhaug, 1998). Our focal lichen species varied extensively in morphology, and lichen species was a better predictor of soil microclimate than was lichen mat thickness in itself. For instance, the soil beneath $C$. islandica became much drier than beneath $S$. paschale, which has thinner mats. This could be due to poor water retention of $C$. islandica combined with its open mat structure and dark color.

This article is protected by copyright. All rights reserved. 


\section{Lichens facilitate seedling recruitment}

We found that the presence of lichens increased seedling recruitment rates compared to recruitment on bare soil. High seedling numbers within lichen mats have also been reported for subarctic forests (Brown \& Mikola, 1974; den Herder, Kytoviita, \& Niemela, 2003; Steijlen, Nilsson, \& Zackrisson, 1995; Zackrisson, Nilsson, Steijlen, \& Hornberg, 1995), and for the treeline ecotone (Dufour-Tremblay, De Vriendt, Lévesque, \& Boudreau, 2012). The recruitment rates within lichens observed in our study (below $40 \%$ for all species except $P$. sylvestris) is within the expectations for such systems (Graae et al., 2011; Steijlen et al., 1995), and therefore contrasts with the negative effects of lichen physical structure and allelopathy on seedling recruitment as reported by Hobbs (1985), Hawkes and Menges (2003), and Sedia and Ehrenfeld (2003) at lower elevations, and possibly more benign environments. Hawkes and Menges (2003) found, however, that the negative effect of lichens was weaker under more severe environmental stress. Indeed, on exposed heaths dominated by terricolous lichens, the vegetation is sparse and the sheltering effect of lichens may be an advantage for seedling recruitment in accordance with the Stress Gradient Hypothesis (Bertness \& Callaway, 1994).

The increased importance of facilitation in stressful habitats could explain the lower recruitment observed on bare soils, as bare soils otherwise tend to promote seedling recruitment, also in arctic-alpine vegetation (Lembrechts et al., 2016; Milbau, Shevtsova, Osler, Mooshammer, \& Graae, 2013). However, recruitment is often better in small gaps, or for big gaps, close to the edge and not in the center, especially in harsh environments (Lembrechts, Milbau, \& Nijs, 2015; Houle \& Filion, 2003). The bare soil plots in our study were quite big and comparable to the severe disturbances performed by Evju et al. (2012) on exposed heaths where few seedlings recruited. Furthermore, the ability of lichens to trap

This article is protected by copyright. All rights reserved. 
seeds (Sedia \& Ehrenfeld, 2003) is important in wind-exposed sites like lichen heaths. This could explain the low recruitment of $S$. glauca and $S$. virgaurea on bare soils in our study, as both species have seeds with hairy appendages that could easily be blown away.

Only lichen species with dense and thick mats (e.g. C. stellaris) seem to negatively affect plant recruitment. This may be caused by a combination of seeds not being able to reach the soil and seedlings not being able to emerge through the mat. Plant species with long and thin cotyledons (e.g. the graminoid A. flexuosa) may establish more successfully in thick and dense mats (cf. the observations of Sydes and Grime (1981) of seedlings emerging in leaf litter).

\section{Lichens affect seedling growth}

Dense and thick lichen mats (e.g. C. stellaris) seem to negatively affect seedling growth of many plant species. Seedling growth of the treeline-forming P. sylvestris (Körner, 2012) was clearly reduced in C. stellaris compared to lichen species forming thinner mats, and this reduced growth, as well as the low recruitment rates, could slow down potential upward migration of $P$. sylvestris into low-alpine $C$. stellaris-dominated heaths. Brown and Mikola (1974) also reported reduced growth of $P$. sylvestris seedlings within $C$. stellaris and suggested that allelopathy restricted ectomycorrhiza formation. In a later study, Kytöviita and Stark (2009) found no negative effect of usnic acid (one of the secondary metabolites in $C$. stellaris) on P. sylvestris growth and suggested other compounds or lichen structure as explanations for the reduced growth. Zamfir (2000) found that light availability decreased dramatically as they moved down the thick $(c .6 \mathrm{~cm})$ lichen mats of Cladonia spp., with only about $7 \%$ of the available light reaching the soil below. We therefore suggest that for $C$. stellaris, low light availability rather than allelopathy during the initial phase of stem and root

This article is protected by copyright. All rights reserved. 
elongation contributed to the growth reduction of $P$. sylvestris and other species in our field experiment.

\section{Limited lichen allelopathic effects on seed germination}

Our laboratory experiment assessing allelopathic effects of lichens suggests no consistent negative effect on seed germination. Some species were more sensitive to the lichen treatments (such as S. acaulis, S. glauca and V. myrtillus), demonstrating the importance of species-specific effects as shown by Escudero, Martínez, de la Cruz, Otálora, and Maestre (2007) and Favero-Longo and Piervittori (2010). In our study only germination of two plant species were seemingly affected by lichen secondary compounds acting alone: S. acaulis with higher germination in lichens devoid of usnic acid (C. islandica and S. paschale), and $V$. myrtillus with highest germination in protolichesterinic-producing lichens $(C$. islandica and F. nivalis). The allelopathic effect of certain metabolites may vary among plant species (Peres et al., 2009), and plant responses to different lichen species may be complicated by mutual adaptation of plants and lichens (Hobbs, 1985). In our study, however, the lichen secondary metabolites were not distinguished from one another or from other compounds, and we cannot ascertain which compounds affected germination. Stereocaulon paschale, for instance, has $\mathrm{N}_{2}$-fixing cyanobacteria (Kytöviita \& Crittenden, 2007), potentially resulting in more available nitrogen (Nash 2008), which in turn may increase germination (Baskin \& Baskin, 2014) and plant growth (Körner, 2003). Although not apparent for all plant species (but for S. acaulis and S. virgaurea), this could have contributed to high germination in the lab as well as recruitment and growth in the field in association with $S$. paschale compared to most of the other lichen species.

This article is protected by copyright. All rights reserved. 
The germination responses to lichens observed in the lab were only partly confirmed in the field, suggesting a minor effect of lichen allelopathy on seed regeneration under natural conditions. We did not measure secondary metabolites under field conditions, but concerning C. stellaris and usnic acid, Stark et al. (2007) found no traces in rainwater percolated through the mat or in the soils beneath. Our findings therefore support recent studies suggesting that allelopathic effects of lichens on vascular plants under natural conditions are weaker than traditionally thought (Favero-Longo \& Piervittori, 2010; Stark et al., 2007).

\section{Conclusions and implications for vegetation dynamics}

Our study shows that lichens facilitate recruitment of vascular plants in dwarf-shrub and lichen heaths, but also that lichen-plant interactions are likely to be species-specific. Overall, the observed lichen-driven modification of microclimate indicates more benign conditions for seedling recruitment. Together, these findings suggest that the ecological importance of lichen allelopathy under natural conditions might be overestimated based on the findings in laboratory experiments, at least in stressful habitats. We might therefore expect most lichens to facilitate rather than hamper vegetation changes in dry tundra heaths. While lichens may facilitate recruitment of seedlings of some species in harsh environments, the effect of lichens may be different for later life stages. High seedling mortality during the first years is common on heaths as well as other tundra habitats (Graae et al. 2011; Milbau et al. 2013), and for heaths associated with low winter temperatures (Milbau et al. 2013). The lichen mats may protect against very low winter temperatures, though, as observed during summer for the species with thick mats. For herbaceous species with broad leaves, re-emerging through the densest lichen mats every spring could get harder as they grow bigger. When seedlings eventually grow past the protective lichen canopy, their survival may depend on adaptations

This article is protected by copyright. All rights reserved. 
to conserve water and withstand wind-erosion and low temperatures, especially on the most exposed heaths.

Nevertheless, vascular plants are expanding at the cost of terricolous lichens e.g. in low-arctic Canada (Fraser et al., 2014) due to increase of tall- and dwarf shrubs, and on Scandinavian low-alpine summits due to increase of the shrub B. nana (Vanneste et al., 2017). Accumulation of leaf litter from deciduous shrubs, or other plant litter, can result in death of fruticose lichens (Cornelissen et al., 2001). This suggests that certain vascular plants, and especially those adapted to drought and/or with prostrate growth forms, such as B. nana (de Groot, Thomas, \& Wein, 1997), are able to expand and outcompete shade-intolerant lichens in heaths despite the stressful environment.

\section{Acknowledgements}

We thank Kongsvoll Biological Station and Norsk Villreinsenter Nord for accommodation. We are grateful to Rozalia Erzsebet Kapas for help in the lab. We also thank The Norwegian Forest Seed Center for donating P. sylvestris seeds.

\section{References}

Ahti, T. (1977). Lichens of the boreal coniferous zone. In M. R. D. Seaward (Ed.), Lichen ecology (pp. 145-181). London, UK: Academic Press.

Allen, A. E. (1929). Influence of Cladonia ground cover on the establishment of seedlings. Ecology, 10, 354-355.

Aune, B. (1993). Air temperature normals, normal period 1961-1990. KLIMA, 02, 1-63.

This article is protected by copyright. All rights reserved. 
Baskin, C. C., \& Baskin, J. M. (2014). Seeds: Ecology, Biogeography and Evolution of Dormancy and Germination. (2nd ed.). San Diego, USA, London, UK, Waltham, USA: Academic Press.

Bates, D., Mächler, M., Bolker, B., \& Walker, S. (2015). Fitting linear mixed-effects models using lme4. Journal of Statistical Software, 67, 1-48. doi:10.18637/jss.v067.i01.

Bertness, M. D., \& Callaway, R. (1994). Positive interactions in communities. Trends in Ecology \& Evolution, 9, 191-193.

Boertje, R. D. (1984). Seasonal diets of the Denali caribou herd, Alaska. Arctic, 37, 161-165.

Broll, G. (2000). Influence of overgrazing by reindeer on soil organic matter and soil microclimate of well-drained soils in the Finnish subarctic. In R. Lal, J. M. Kimble, \& B. A. Steward (Eds.), Global climate change and cold regions ecosystems (pp. 163-172). Boca Raton, USA: CRC Press.

Brown, R. T., \& Mikola, P. (1974). The influence of fruticose soil lichens upon the mycorrhizae and seedling growth of forest trees. Acta Forestalia Fennica, 141, 5-23.

Cavieres, L. A., Badano, E. I., Sierra-Almeida, A., \& Molina-Montenegro, M. A. (2007).

Microclimatic modifications of cushion plants and their consequences for seedling survival of native and non-native herbaceous species in the High Andes of Central Chile. Arctic, Antarctic, and Alpine Research, 39, 229-236.

Cornelissen, J. H. C., Callaghan, T. V., Alatalo, J., Michelsen, A., Graglia, E., Hartley, A., . . . Robinson, C. H. (2001). Global change and arctic ecosystems: is lichen decline a function of increases in vascular plant biomass? Journal of Ecology, 89, 984-994.

This article is protected by copyright. All rights reserved. 
Crittenden, P. D. (1989). Nitrogen relations of mat-forming lichens. In L. Boddy, R.

Marchant, \& D. J. Read (Eds.), Nitrogen, Phosphorus and Sulphur Utilisation by Fungi (pp. 243-268). Cambridge: Cambridge University Press.

Crittenden, P. D. (2000). Aspects of the ecology of mat-forming lichens. Rangifer, 20, $127-$ 139.

Danell, K., Utsi, P. M., Palo, R. T., \& Eriksson, O. (1994). Food plant selection by reindeer during winter in relation to plant quality. Ecography, 17, 153-158. doi:10.1111/j.16000587.1994.tb00088.x

de Groot, W., Thomas, P., \& Wein, R. W. (1997). Betula nana L. and Betula glandulosa Michx. Journal of Ecology, 85, 241-264.

den Herder, M., Kytoviita, M. M., \& Niemela, P. (2003). Growth of reindeer lichens and effects of reindeer grazing on ground cover vegetation in a Scots pine forest and a subarctic heathland in Finnish Lapland. Ecography, 26, 3-12. doi:10.1034/j.1600-0587.2003.03211.x

Dufour-Tremblay, G., De Vriendt, L., Lévesque, E., \& Boudreau, S. (2012). The importance of ecological contraints on the control of multi-species treeline dynamics in eastern Nunavik, Québec. American Journal of Botany, 99, 1638-1646. doi:10.3732/ajb.1200279

Escudero, A., Martínez, I., de la Cruz, A., Otálora, M. A. G., \& Maestre, F. T. (2007). Soil lichens have species-specific effects on the seedling emergence of three gypsophile plant species. Journal of Arid Environments, 70, 18-28. doi:http://dx.doi.org/10.1016/j.jaridenv.2006.12.019

Evju, M., Hagen, D., \& Hofgaard, A. (2012). Effects of disturbance on plant regrowth along snow pack gradients in alpine habitats. Plant Ecology, 213, 1345-1355.

This article is protected by copyright. All rights reserved. 
Favero-Longo, S. E., \& Piervittori, R. (2010). Lichen-plant interactions. Journal of Plant Interactions, 5, 163-177. doi:10.1080/17429145.2010.492917

Fenner, M., \& Thompson, K. (2005). The ecology of seeds. Cambridge, UK: Cambridge University Press.

Fisher, R. (1979). Possible allelopathic effects of reindeer-moss (Cladonia) on jack pine and white spruce. Forest Science, 25, 256-260.

Fraser, R. H., Lantz, T. C., Olthof, I., Kokelj, S. V., \& Sims, R. A. (2014). Warming-induced shrub expansion and lichen decline in the Western Canadian Arctic. Ecosystems, 17, 11511168.

Førland, E. J. (1993). Precipitation normals, Normal period 1961-1990. KLIMA, 39, 1-63.

Fremstad, E. 1997. Vegetasjonstyper i Norge. Norsk Institutt for Naturforskning, Temahefte $12,1-279$.

Gauslaa, Y., \& Solhaug, K. A. (1998). The significance of thallus size for the water economy of the cyanobacterial old-forest lichen Degelia plumbea. Oecologia, 116, 76-84.

Graae, B. J., Ejrnæs, R., Lang, S. I., Meineri, E., Ibarra, P. T., \& Bruun, H. H. (2011). Strong microsite control of seedling recruitment in tundra. Oecologia, 166, 565-576. doi:10.1007/s00442-010-1878-8

Graae, B. J., De Frenne, P., Kolb, A., Brunet, J., Chabrerie, O., Verheyen, K., . . Milbau, A. (2012). On the use of weather data in ecological studies along altitudinal and latitudinal gradients. Oikos, 121, 3-19. doi:10.1111/j.1600-0706.2011.19694.x

This article is protected by copyright. All rights reserved. 
Haapasaari, M. (1988). The oligotrophic heath vegetation of northern Fennoscandia and its zonation. Acta Botanica Fennica, 135, 1-219.

Hawkes, C. V., \& Menges, E. S. (2003). Effects of lichens on seedling emergence in a xeric Florida shrubland. Southeastern Naturalist, 2, 223-234. doi:10.1656/1528-

7092(2003)002[0223:EOLOSE]2.0.CO;2

Hobbs, R. J. (1985). The persistence of Cladonia patches in closed heathland stands. The Lichenologist, 17, 103-109.

Holien, H., \& Tønsberg, T. (2008). Norsk lavflora (2nd ed.). Trondheim: Tapir akademisk forlag.

Hothorn, T., Bretz, F., \& Westfall, P. (2008). Simultaneous inference in general parametric models. Biometrical Journal, 50, 346-363.

Houle, G., \& Filion, L. (2003). The effects of lichens on white spruce seedling establishment and juvenile growth in a spruce-lichen woodland of subarctic Québec Ecoscience, 10, 80-84. doi:10.1080/11956860.2003.11682754

Kershaw, K., \& Rouse, W. (1971). Studies on lichen-dominated systems. I. The water relations of Cladonia alpestris in spruce-lichen woodland in northern Ontario. Canadian Journal of Botany, 49, 1389-1399.

Kershaw, K. (1977). Studies on lichen-dominated systems. XX. An examination of some aspects of the northern boreal lichen woodlands in Canada. Canadian Journal of Botany, 55, $393-410$.

Körner, C. (2003). Alpine plant life: Functional plant ecology of high mountain ecosystems (2nd ed.). Berlin, Heidelberg, New York: Springer.

This article is protected by copyright. All rights reserved. 
Körner, C. (2012). Alpine treelines: Functional ecology of the global high elevation tree limits. Basel: Springer.

Krog, H., Østhagen, H., \& Tønsberg, T. (1994). Lavflora: norske busk- og bladlav (2nd ed.). Oslo: Universitetsforlaget.

Kytöviita, M.-M., \& Crittenden, P. D. (2007). Growth and nitrogen relations in the matforming lichens Stereocaulon paschale and Cladonia stellaris. Annals of Botany, 100, 15371545. doi:10.1093/aob/mcm249

Kytöviita, M.-M., \& Stark, S. (2009). No allelopathic effect of the dominant forest floor lichen Cladonia stellaris on pine seedlings. Functional Ecology, 23, 435-441.

Lange, O. L., Hahn, S. C., Meyer, A., \& Tenhunen, J. D. (1998). Upland tundra in the foothills of the Brooks Range, Alaska, USA: lichen long-term photosynthetic $\mathrm{CO}_{2}$ uptake and net carbon gain. Arctic and Alpine Research, 30, 252-261.

Larson, D. (1979). Lichen water relations under drying conditions. New Phytologist, 82, 713731.

Larson, D. (1981). Differential wetting in some lichens and mosses: the role of morphology. Bryologist, 84, 1-15.

Larson, D. (1987). The absorption and release of water by lichens. In E, Peveling (Ed.), Bibliotheca lichenologica, Progress and Problems in Lichenology in the Eighties (Vol. 25, pp. 351-360). Berlin: J. Cramer.

Latkowska, E., Bialczyk, J., Lechowski, Z., \& Czaja-Prokop, U. (2008). Responses in tomato roots to stress caused by exposure to (+)-usnic acid. Allelopathy Journal, 21, 239.

This article is protected by copyright. All rights reserved. 
Lembrechts, J. J., Milbau, A., \& Nijs, I. (2015). Trade-off between competition and facilitation defines gap colonization in mountains. AoB PLANTS, 7, plv128.

doi:10.1093/aobpla/plv128

Lembrechts, J. J., Pauchard, A., Lenoir, J., Nuñez, M. A., Geron, C., Ven, A., . . Milbau, A. (2016). Disturbance is the key to plant invasions in cold environments. Proceedings of the National Academy of Sciences, 113, 14061-14066.

Lenth, R. (2017). emmeans: Estimated Marginal Means, aka Least-Squares Means. R package version 1.0. Retrieved from https://CRAN.R-project.org/package=emmeans

Løkken, J. O., Hofgaard, A., Dalen, L., \& Hytteborn, H. (2019). Grazing and warming effects on shrub growth and plant species composition in subalpine dry tundra - an experimental approach. Journal of Vegetation Science. Advance online publication. doi:10.1111/jvs.12752

Maliniemi, T., Kapfer, J., Saccone, P., Skog, A., \& Virtanen, R. (2018). Long-term vegetation changes of treeless heath communities in northern Fennoscandia: Links to climate change trends and reindeer grazing. Journal of Vegetation Science, 29, 469-479. doi:10.1111/jvs.12630

Milbau, A., Shevtsova, A., Osler, N., Mooshammer, M., \& Graae, B. J. (2013). Plant community type and small-scale disturbances, but not altitude, influence the invasibility in subarctic ecosystems. New Phytologist, 197, 1002-1011. doi:10.1111/nph.12054

Molau, U., \& Larsson, E. L. (2000). Seed rain and seed bank along an alpine altitudinal gradient in Swedish Lapland. Canadian Journal of Botany, 78, 728-747. doi:10.1139/b00049

This article is protected by copyright. All rights reserved. 
Moles, A. T., \& Westoby, M. (2004). What do seedlings die from and what are the implications for evolution of seed size? Oikos, 106, 193-199.

Molina-Montenegro, M. A., Ricote-Martinez, N., Munoz-Ramirez, C., Gomez-Gonzalez, S., Torres-Diaz, C., Salgado-Luarte, C., \& Gianoli, E. (2013). Positive interactions between the lichen Usnea antarctica (Parmeliaceae) and the native flora in Maritime Antarctica. Journal of Vegetation Science, 24, 463-472. doi:10.1111/j.1654-1103.2012.01480.x

Nash III, T. H. (Ed.) (2008). Lichen biology (2nd ed.). Cambridge, UK: Cambridge University Press.

Nellemann, C., Jordhøy, P., Støen, O.-G., \& Strand, O. (2000). Cumulative impacts of tourist resorts on wild reindeer (Rangifer tarandus tarandus) during winter. Arctic, 53, 9-17.

Nishitoba, Y., Nishimura, I., Nishiyama, T., \& Mizutani, J. (1987). Lichen acids, plant growth inhibitors from Usnea longissima. Phytochemistry, 26, 3181-3185.

Oksanen, F. J., Blanchet, F. G., Friendly, M., Kindt, R., Legendre, P., McGlinn, D., . . . Wagner, H. (2017). vegan: Community Ecology Package. R package version 2.4-5. Retrieved from https://CRAN.R-project.org/package=vegan

Opedal, Ø. H., Armbruster, W. S., \& Graae, B. J. (2015). Linking small-scale topography with microclimate, plant species diversity and intra-specific trait variation in an alpine landscape. Plant Ecology \& Diversity, 8, 305-315.

Palmquist, K. D., L. Jonsson, \& A. Nash III T. H. (2008). The carbon ecology of lichens. In T. H. Nash (Ed.), Lichen Biology (2nd ed., pp. 182-215). Cambridge, UK: Cambridge University Press.

This article is protected by copyright. All rights reserved. 
Peres, M. T. L. P., Mapeli, A. M., Faccenda, O., Gomes, A. T., \& Honda, N. K. (2009). Allelopathic potential of orsellinic acid derivatives. Brazilian Archives of Biology and Technology, 52, 1019-1026.

Pyatt, F. B. (1967). The inhibitory influence of Peltigera canina on the germination of graminaceous seeds and the subsequent growth of the seedlings. Bryologist, 326-329.

Scherrer, D., \& Körner, C. (2011). Topographically controlled thermal habitat differentiation buffers alpine plant diversity against climate warming. Journal of biogeography, 38, 406-416.

Sedia, E. G., \& Ehrenfeld, J. G. (2003). Lichens and mosses promote alternate stable plant communities in the New Jersey Pinelands. Oikos, 100, 447-458.

Stark, S., \& Hyvärinen, M. (2003). Are phenolics leaching from the lichen Cladina stellaris sources of energy rather than allelopathic agents for soil microorganisms? Soil Biology and Biochemistry, 35, 1381-1385.

Stark, S., Kytöviita, M.-M., \& Neumann, A. B. (2007). The phenolic compounds in Cladonia lichens are not antimicrobial in soils. Oecologia, 152, 299-306. doi:10.1007/s00442-0060644-4

Steijlen, I., Nilsson, M.-C., \& Zackrisson, O. (1995). Seed regeneration of Scots pine in boreal forest stands dominated by lichen and feather moss. Canadian Journal of Forest Research, 25, 713-723. doi:10.1139/x95-079

Sydes, C., \& Grime, J. (1981). Effects of tree leaf litter on herbaceous vegetation in deciduous woodland: II. An experimental investigation. Journal of Ecology, 69, 249-262.

This article is protected by copyright. All rights reserved. 
Tigre, R., Silva, N., Santos, M., Honda, N., Falcão, E., \& Pereira, E. (2012). Allelopathic and bioherbicidal potential of Cladonia verticillaris on the germination and growth of Lactuca sativa. Ecotoxicology and Environmental Safety, 84, 125-132.

Vanneste, T., Michelsen, O., Graae, B. J., Kyrkjeeide, M. O., Holien, H., Hassel, K., . . De Frenne, P. (2017). Impact of climate change on alpine vegetation of mountain summits in Norway. Ecological Research, 32, 579-593. doi:10.1007/s11284-017-1472-1

Vistnes, I. I., \& Nellemann, C. (2008). Reindeer winter grazing in alpine tundra: impacts on ridge community composition in Norway. Arctic, Antarctic, and Alpine Research, 40, 215224. doi:10.1657/1523-0430(07-001)[VISTNES]2.0.CO;2

Vuorinen, K. E. M., Oksanen, L., Oksanen, T., Pyykönen, A., Olofsson, J., \& Virtanen, R. (2017). Open tundra persist, but arctic features decline-Vegetation changes in the warming Fennoscandian tundra. Global Change Biology, 23, 3794-3807. doi:10.1111/gcb.13710

Warnes, G. R., Bolker, B., Bonebakker, L., Gentleman, R., Liaw, W. H. A., Lumley, T., . . . Venables, B. (2019). gplots: Various R programming tools for plotting data. R package version 3.0.1.1. Retrieved from https://CRAN.R-project.org/package=gplots

Zackrisson, O., Nilsson, M.-C., Steijlen, I., \& Hornberg, G. (1995). Regeneration pulses and climate-vegetation interactions in nonpyrogenic boreal Scots pine stands. Journal of Ecology, 469-483.

Zamfir, M. (2000). Effects of bryophytes and lichens on seedling emergence of alvar plants: evidence from greenhouse experiments. Oikos, 88, 603-611.

This article is protected by copyright. All rights reserved. 


\section{Tables}

Table 1: Characteristics of lichen and vascular plant species used in the study, including growth form (fruticose here referring to lichens with upright, shrub-like thalli with cylindrical branches, and cetrarioid to lichens with upright, modified lobed and leaf-like thalli with dorsiventral morphology), mat thickness in the field experiment (mean $\pm \mathrm{SE}, \mathrm{n}=8$ except for 7 in $C$. islandica) and secondary metabolites of the lichen species, and growth form and seed mass (mg) of the plant species. The lichen species are listed by increasing mat thickness.

\begin{tabular}{|c|c|c|c|}
\hline Lichen species & Growth form & $\begin{array}{l}\text { Mat } \\
\text { thickness } \\
(\mathrm{cm})\end{array}$ & Secondary metabolites* \\
\hline Flavocetraria nivalis & Cetrarioid & $1.9 \pm 0.2$ & Usnic acid and protolichesterinic acid \\
\hline Alectoria ochroleuca & Fruticose & $1.9 \pm 0.4$ & Usnic acid and diffractaic acid \\
\hline Stereocaulon paschale & Fruticose & $2.1 \pm 0.2$ & Atranorin and lobaric acid \\
\hline Cetraria islandica & Cetrarioid & $2.6 \pm 0.3$ & Fumarprotocetraric acid and protolichesterinic acid \\
\hline Cladonia arbuscula & Fruticose & $3.8 \pm 0.3$ & Usnic acid and fumarprotocetraric acid \\
\hline Cladonia stellaris & Fruticose & $6.8 \pm 0.4$ & Usnic acid and perlatolic acid \\
\hline Vascular plant species & Growth form & \multicolumn{2}{|c|}{ Seed mass $(\mathrm{mg})^{* *}$} \\
\hline Anthoxanthum nipponicum & Graminoid & \multicolumn{2}{|l|}{0.4878} \\
\hline Avenella flexuosa & Graminoid & \multicolumn{2}{|l|}{0.5} \\
\hline Betula nana & Shrub & \multicolumn{2}{|l|}{0.3184} \\
\hline Bistorta vivipara & Forb & \multicolumn{2}{|l|}{2.73} \\
\hline Dryas octopetala & Dwarf shrub & \multicolumn{2}{|l|}{0.706} \\
\hline Luzula spicata & Graminoid & \multicolumn{2}{|l|}{0.259} \\
\hline Pinus sylvestris & Tree & \multicolumn{2}{|l|}{6.0} \\
\hline Salix glauca & Shrub & \multicolumn{2}{|l|}{0.163} \\
\hline Silene acaulis & Forb & \multicolumn{2}{|l|}{0.3} \\
\hline Solidago virgaurea & Forb & \multicolumn{2}{|l|}{0.55} \\
\hline Vaccinium myrtillus & Dwarf shrub & \multicolumn{2}{|l|}{0.3} \\
\hline
\end{tabular}

This article is protected by copyright. All rights reserved. 


\section{Figures}

Figure 1: Visual representation of how lichens may affect the recruitment phase of vascular plants. In scenario (a) lichen allelopathy inhibits seed germination and early seedling development and reduces the number of mycorrhizae associations of the seedling. In scenario (b) the physical structure of lichen mats prevents seeds and root radicles of germinating seeds from reaching the soil, and emerging seedlings may fail to penetrate the lichen mat. In scenario (c) lichens may facilitate plant recruitment by modifying the microclimate, in particular shelter against wind, extreme temperatures, and drought, which are harmful for emerging seedlings.

Figure 2: Estimated soil microclimate conditions in the field experiment with temperature (maximum, mean and minimum) (a) and moisture (wet and dry day) (b) with 95\% confidence intervals for each lichen treatment. Treatments with no letters in common are significantly different $(p<0.05)$, tested using multiple comparisons with the Tukey method. The lichen treatments are ordered by increasing mat thickness and abbreviated as follows: Co; Control (bare soil), Fn; Flavocetraria nivalis, Ao; Alectoria ochroleuca, Sp; Stereocaulon paschale, $\mathrm{Ci}$; Cetraria islandica, Ca; Cladonia arbuscula and Cs; Cladonia stellaris.

Figure 3: Seedling recruitment in the field experiment across lichen treatments. (a) Barplots showing mean estimated seedling recruitment and $95 \%$ confidence intervals. Notice that the recruitment scale of $P$. sylvestris differ from the other plant species. The lichen treatments are ordered by increasing mat thickness and abbreviated as follows: Co; Control (bare soil), Fn; Flavocetraria nivalis, Ao; Alectoria ochroleuca, Sp; Stereocaulon paschale, Ci; Cetraria islandica, Ca; Cladonia arbuscula and Cs; Cladonia stellaris. Treatments with no letters in 
common are significantly different $(p<0.05)$, as revealed by pairwise comparisons. (b) Heat map of mean estimated seedling recruitment rates in the lichen treatments with clustering of plants (top) and lichen treatments (left). The plant and lichen dendrogram were cut at manually chosen heights (see Appendix S7).

Figure 4: Estimated biomass (mg dry weight) of the emerged seedlings in the field experiment across lichen treatments with 95\% confidence intervals. Notice that the seedling weight scale of the heavy $P$. sylvestris and $S$. virgaurea differ from the six other plant species. Legends show number of seedlings emerged in each lichen treatment. The lichen treatments are ordered by increasing mat thickness and abbreviated as follows: Co; Control (bare soil), Fn; Flavocetraria nivalis, Ao; Alectoria ochroleuca, Sp; Stereocaulon paschale, Ci; Cetraria islandica, Ca; Cladonia arbuscula and Cs; Cladonia stellaris. Treatments with no letters in common are significantly different $(p<0.05)$, as revealed by pairwise comparisons.

Figure 5: Seed germination in the laboratory experiment across lichen treatments. (a) Barplots showing mean estimated seed germination and 95\% confidence intervals. The lichen treatments are abbreviated as follows: Co; Control (water only), Fn; Flavocetraria nivalis, Ao; Alectoria ochroleuca, Sp; Stereocaulon paschale, Ci; Cetraria islandica, Ca; Cladonia arbuscula and Cs; Cladonia stellaris. Treatments with no letters in common are significantly different $(p<0.05)$, as revealed by pairwise comparisons. (b) Heat map of mean estimated mean germination rates in the lichen treatments with clustering of plants (top) and lichen treatments (left). The lichen treatment dendrogram did not separate until height 0.38 and supported no ecologically meaningful clustering of the lichens (see Appendix S7).

This article is protected by copyright. All rights reserved. 


\section{Supporting Information}

Appendix S1: Schematic figure and photo of the field design.

Appendix S2: Figure with number of live and dead seedlings in the lichen treatments after one year.

Appendix S3: Table with model selection results for the four first research questions in the study.

Appendix S4: Anova and summary statistic tables of the models presented in the manuscript. Appendix S5: Seedling recruitment and biomass data for the field experiment.

Appendix S6: Seed germination data for the laboratory experiment.

Appendix S7: Dendrograms for lichen treatments and plant species used in Fig. 3 and Fig. 5 with heights.

This article is protected by copyright. All rights reserved. 


\section{Potential lichen-plant recruitment interactions in lichen heaths}

(a) Negative

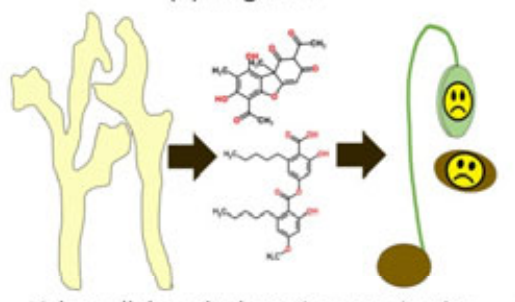

Lichen allelopathy lowering germination and seedling performance (b) Negative

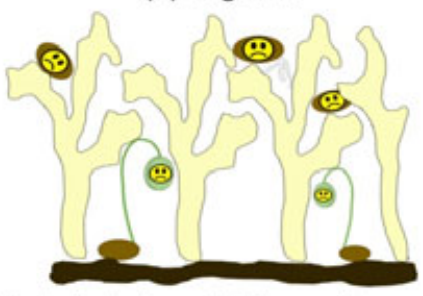

Physical structure of lichens acting as a barrier for seeds and seedlings (c) Facilitative

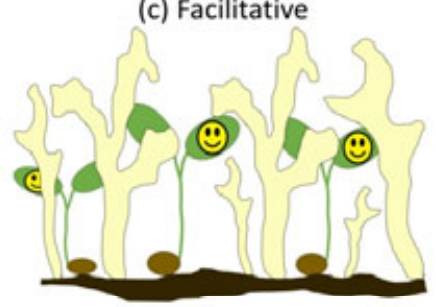

Lichen mats modifying microclimate, favoring seedling recruitment

(a)

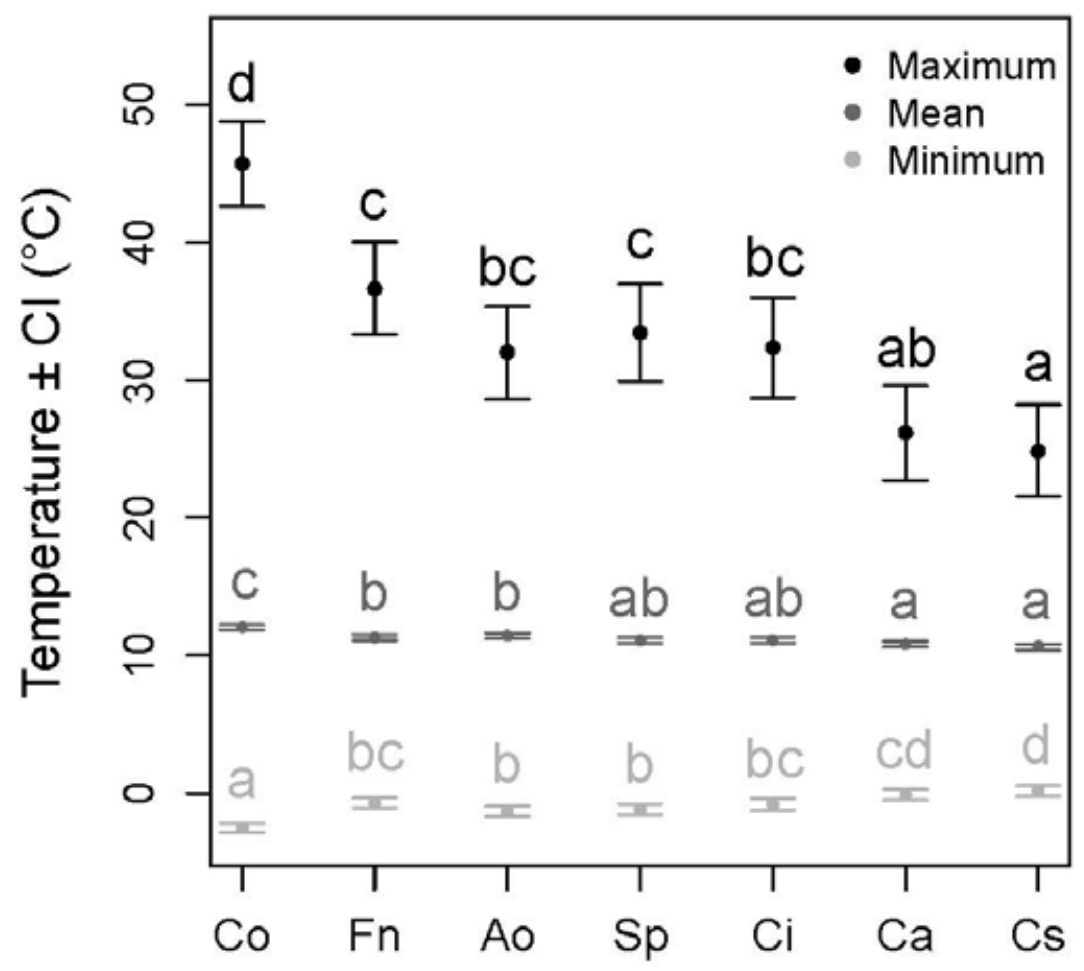

This article is protected by copyright. All rights reserved. 
(b)

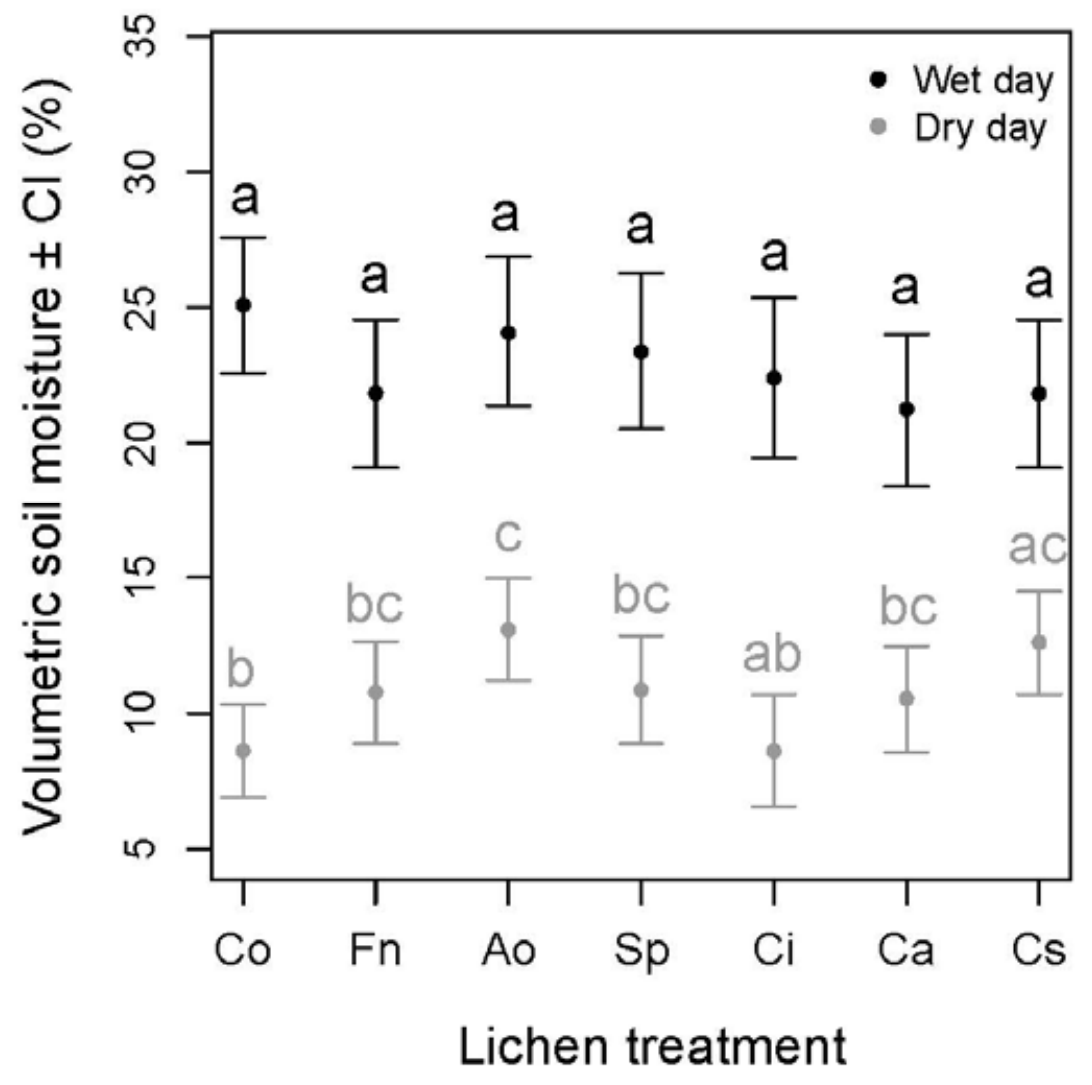

This article is protected by copyright. All rights reserved. 
(a) Field seedling recruitment barplots
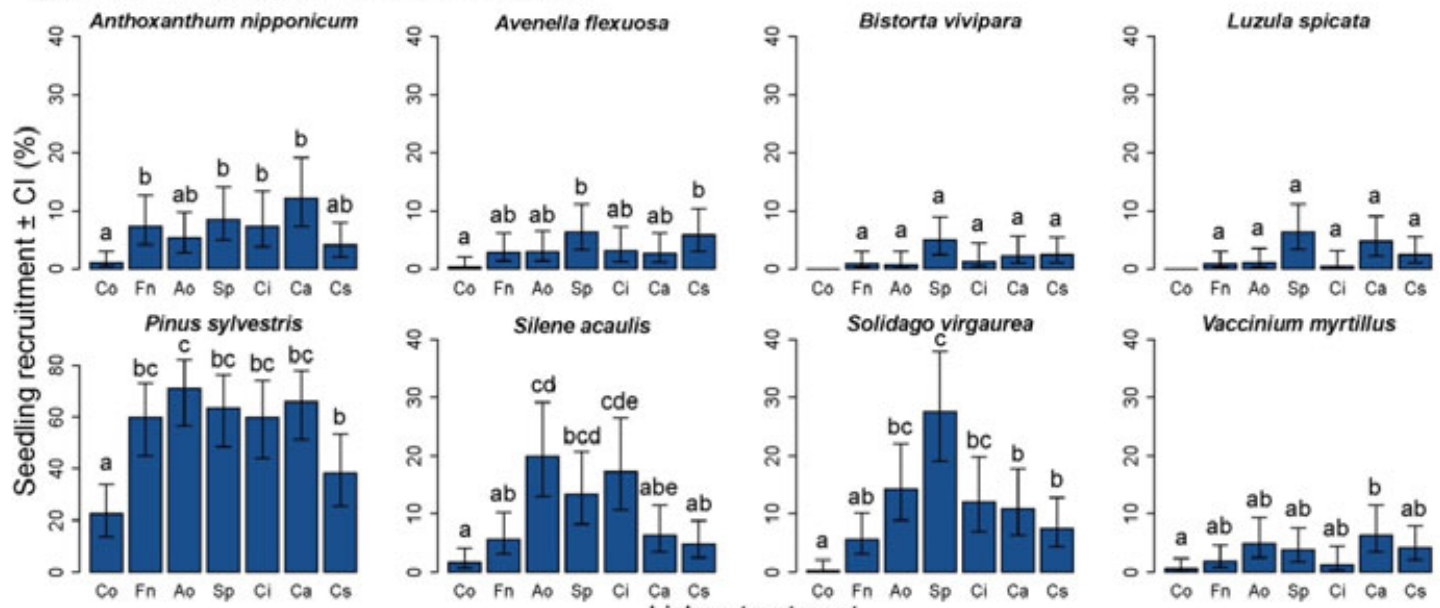

(b) Field seedling recruitment heatmap

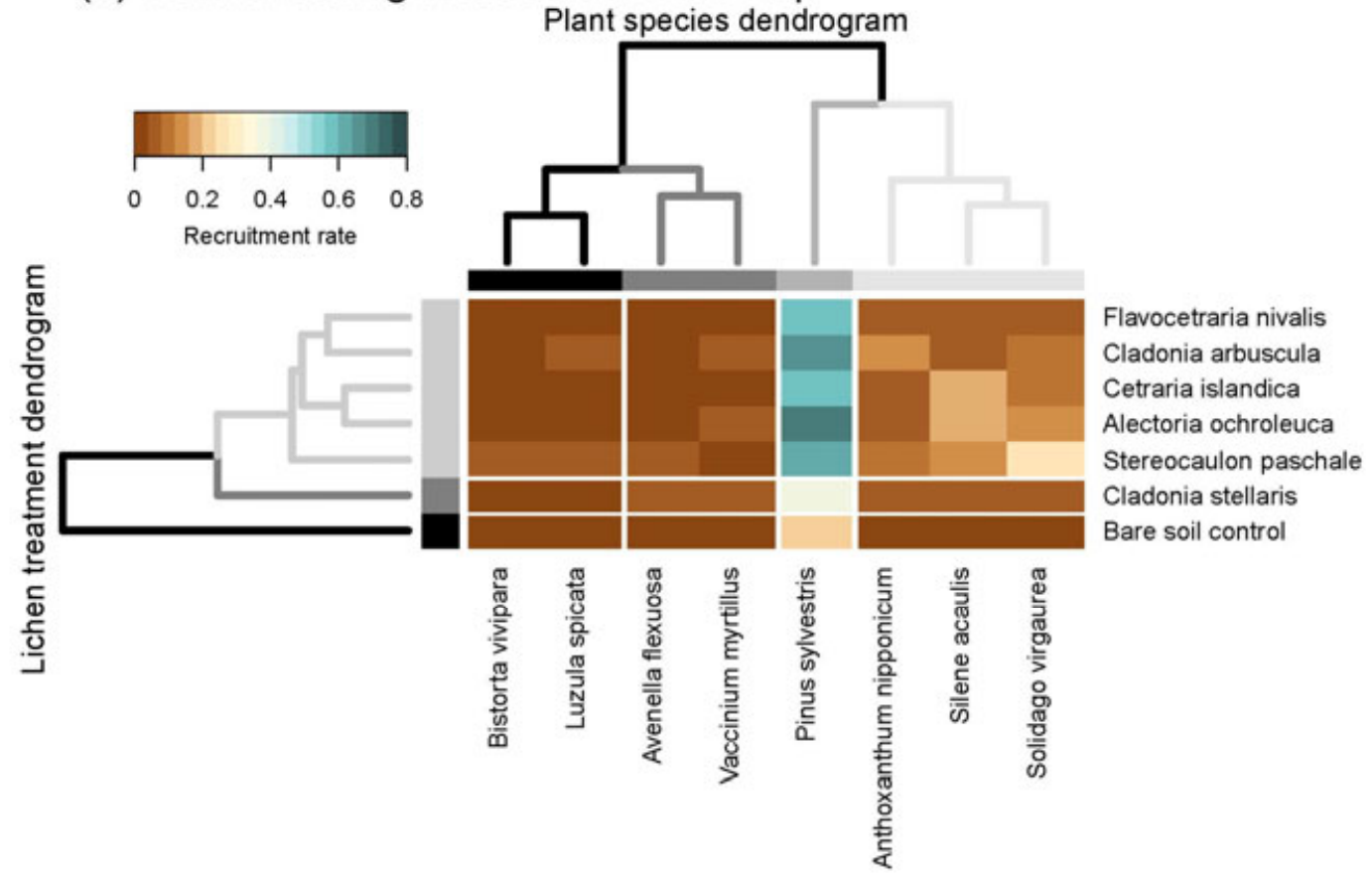

This article is protected by copyright. All rights reserved. 

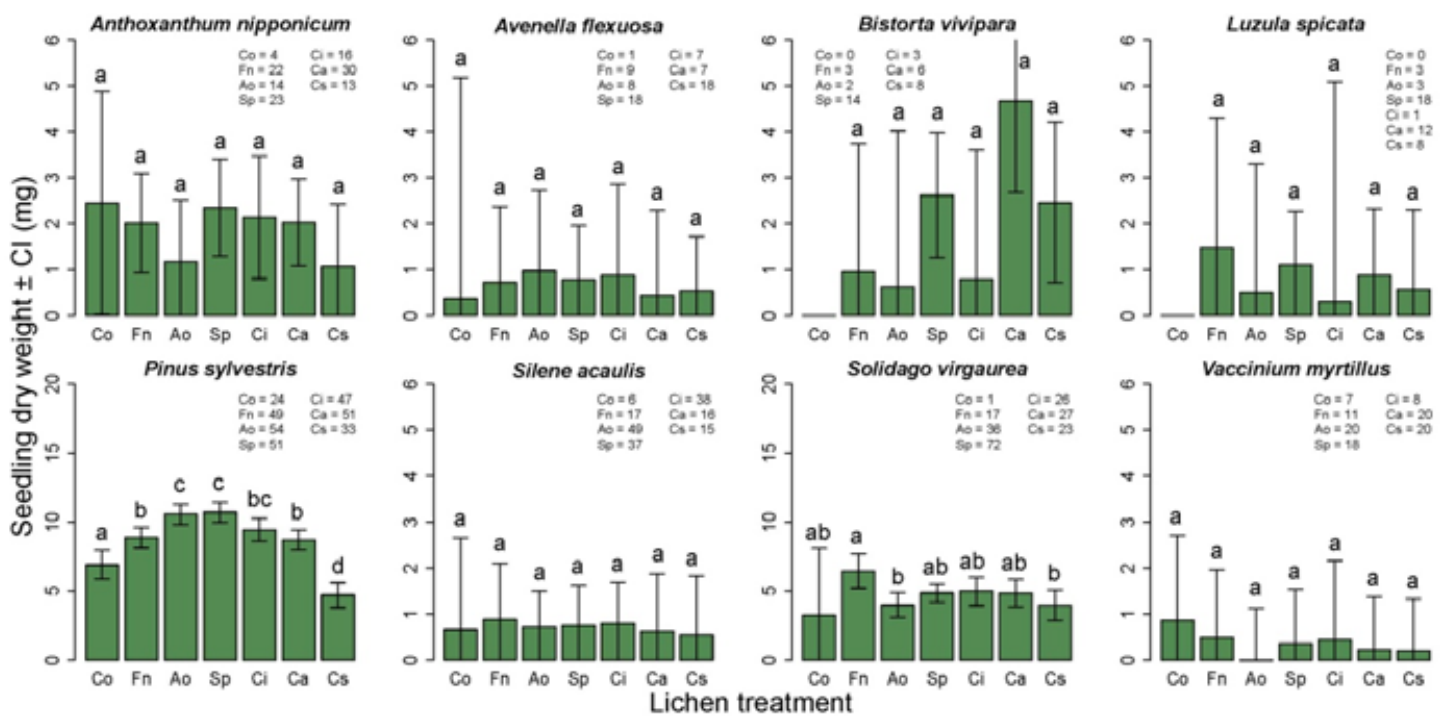

(a) Lab seed germination barplots
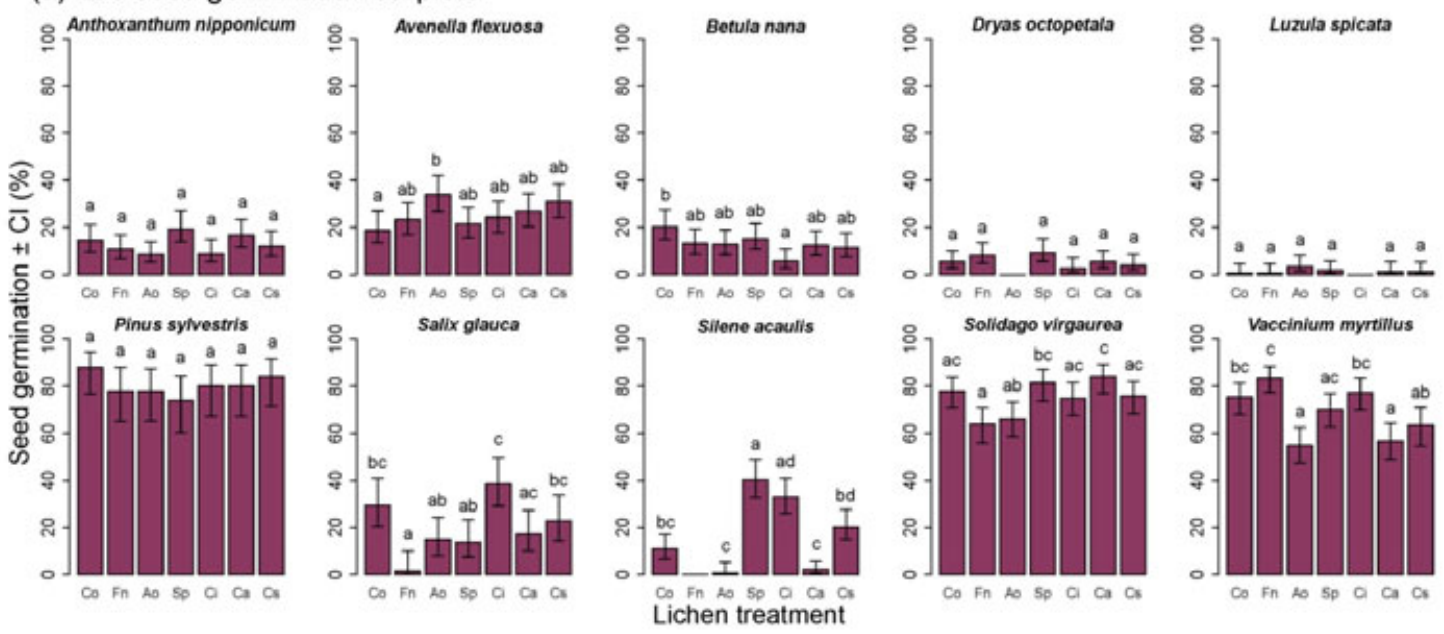

This article is protected by copyright. All rights reserved. 
(b) Lab seed germination heatmap

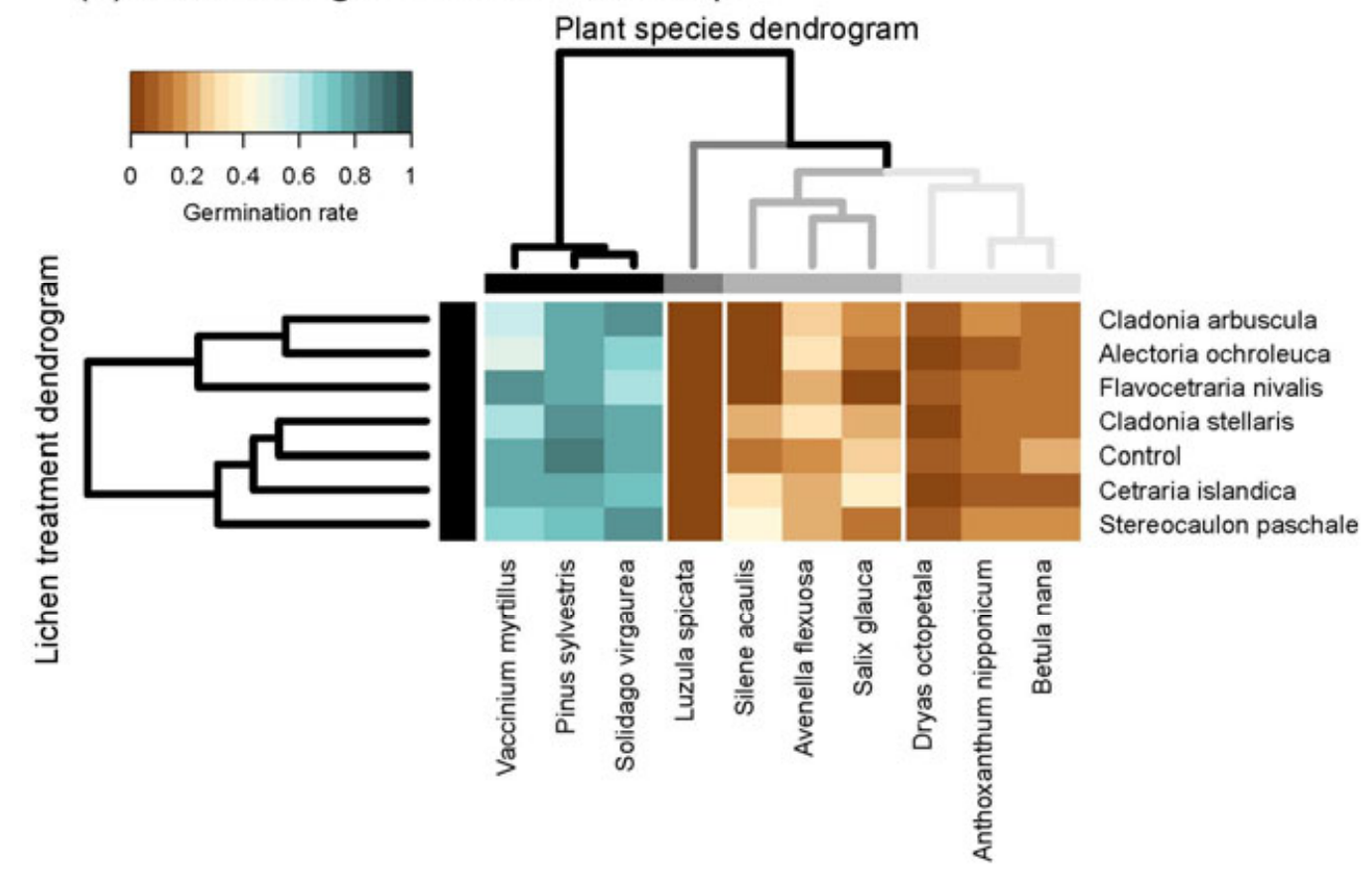

Plant species dendrogram

This article is protected by copyright. All rights reserved. 